\title{
C.H. Holland, I.S. Sanders (eds): The Geology of Ireland, 2nd edn
}

2009, Dunedin Academic Press, Edinburgh, Scotland. ISBN 9781903763722, paperback, US \$160, 568 pp, 19 chapters

This book builds on the original A Geology of Ireland (1981) and the first edition of The Geology of Ireland (2001) by expanding the scope of coverage; providing detailed colored plates, maps and cross-sections; and updating the content based on new research technologies.

The nineteen separate chapters are authored by wellknown names in their fields, including J.S. Daly, D. Naylor, J. Preston, and D.M. Chew, among others. Data is presented in a straightforward and unassuming style. To read this book is to take a stroll through geologic time, accompanied by richly colored photographs which illustrate outcrops of the various formations.

This publication is useful as a college-level reference text on stratigraphy, an in-depth field guidebook, and an enjoyable read for the armchair traveler.

Dr. Barry F. Beck

P.E. LaMoreaux and Associates, Oak Ridge, TN, USA

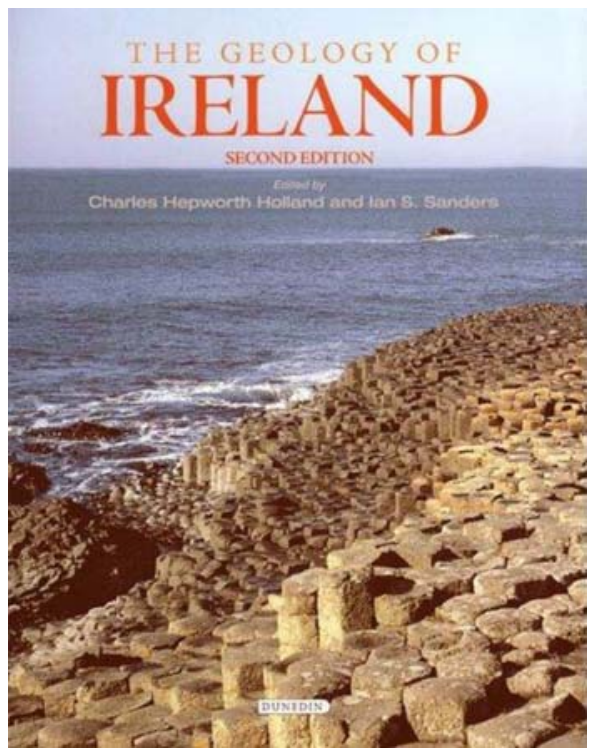

